\title{
The Impact of Income Diversification and Non-Interest Income Diversification on Indonesian Bank Performance, 2012-2017
}

\author{
Dediek Tri Kurniawan*, Ely Siswanto
}

\author{
Department of Management, State University of Malang, Malang, Indonesia \\ ${ }^{*}$ Corresponding author. Email: dediektrikurniawan@gmail.com
}

\begin{abstract}
The influence of diversification decisions is still debated in several studies. Some studies highlight the positive impact of diversification on company performance. On the other hand, diversification has also been considered to have a negative impact on companies. The negative impacts from diversification activities are often referred to as the dark side of diversification. This study examines the impact of income diversification, non-interest income diversification, bank size, loan proportion, and non-performing loans on bank performance. Income diversification and non-interest income diversification were tested at the same time. Forty-one Indonesian banks were examined for the period 2012 2017. The period was considered to be challenging for banks in Indonesia because of a fluctuating economic situation. This study found that income diversification, non-interest income diversification, and non-performing loans negatively influenced bank performance. Bank size had a positive effect on bank performance and loan proportions were not proven to have any effect on bank performance.
\end{abstract}

Keywords: Income Diversification, Non-Interest Income Diversification, Bank Performance, Indonesia

\section{INTRODUCTION}

The relationship between diversification and performance has been explored by many researchers from various scientific disciplines such as economics, finance, and management strategies (Benito-Osorio, Guerras-Martin, and Zuniga-Vicente, 2012). The influence of diversification decisions is still debated in several studies. Some studies highlight the positive impacts of diversification on company performance. On the other hand, diversification has also been considered to have a negative impact on companies. The negative impacts from diversification activities are often referred to as "the dark side of diversification (Stiroh and Rumble, 2006)." Diversification can be a double-edged sword where one side can make a company more profitable but the other can require the company to incur a number of costs in order to realize the desired objective (Kang, Lee, and Yang, 2010). Diversification activities can certainly increase costs, which will have an impact on the company's performance. Diversification also causes the company to lose potential investments in activities due to the diversification decision.
The strategic focus theory argues that diversified companies tend to face difficulties in monitoring multiple businesses because of high agency costs (Alhassan, 2015; Deng and Elyasiani, 2008; DeYoung. and Roland, 2001; Leaven and Levine, 2007; and Stiroh, 2004) and this causes inefficiency (Rajan, Servaes and Zingales, 2000). According to agency theory, agency conflict can potentially occur anytime the owner is not a manager in a company. In fact, corporate investment is always influenced by the efforts of managers (Jensen and Meckling, 1976; Riaz, Shahab, Bibi, and Zeb, 2016;). Diversification has the potential to increase agency costs (Rotemberg and Saloner, 1994) and inefficiency in subsidized units that perform poorly (Rajan, Servaes and Zingales, 2000). The agency relationship is defined as the relationship between shareholders and management where management is hired to effectively manage the organization in the interest of the shareholders (Hillier, Ross, Jaffe, and Jordan, 2010).

In addition, the "new toy effect" described by Schoar (2002) is a phenomenon related to the negative effects 
of diversification when managers are more focused on new assets than on existing divisions of the company. When a company diversifies through acquisition or the creation of new facilities, it can cause a decrease in productivity. This effect is illustrated when the focus of managers begins to move from long-running activities to the latest investment activities. The existence of new business units can cause managers to ignore core competencies of the company. This condition is certainly very risky, and there is the potential of losing an existing business.

The conglomeration theory states that diversification has a positive impact on company performance. The theory argues that diversification activities guarantee the maximization of a managerial business in different operational aspects. Cost sharing of product diversity and revenue segments are expected to produce benefits through economies of scope. (Alhassan, 2015). Research about diversification in the banking industry is still relevant because the previous research on this topic has been inconsistent.

This research examined the effect of income diversification (both income diversification and noninterest income diversification) on Indonesian bank performance for the period 2012-2017. This period was a challenging time for Indonesian banks because of a fluctuating economy. Loan growth began to slow down to approximately $21.97 \%$ in 2012 (previous period reached $23.35 \%$ in 2011). To maintain financial performance, banks must anticipate slowing loan growth by increasing other sources of income. This condition continued in 2013 when loan growth was $21.80 \%$ and $7.85 \%$ in 2016. Economic conditions had decreased people's purchasing power.

According to data from the Indonesia Financial Services Authority (Otoritas Jasa Keuangan (OJK)), there were 115 banks operating in Indonesia in 2017. This number has decreased compared to 2012, when there were about 120 banks operating in Indonesia. In addition, the average number of bank offices was recorded as 32.285 units in all areas in Indonesia. This number has also decreased compared to 2016 when it was about 32.730 units. This means that there were 445 office unit closures in 2017. The number of offices in 2016 had also decreased when compared to 2015 (about 219 units closed).

\section{LITERATURE REVIEW}

Diversification is defined as the spread of an organization beyond its boundaries into other markets (subsectors) within an industry or areas (geography) to increase and improve performance by decreasing existing risks and increasing returns (Oyewobi, Windapo, and Cattell, 2013). Diversification of the market or the product comes from the company considering different business strategies that can increase performance. This development can involve diversification of strategies and market concentration (Mintzberg, Ahlstrand, and Lampel, 2009).

DeYoung and Rice stated that non-interest income tends to be seen as existing beside interest income from intermediation activities (loans), which are still the main function of financial services (2004). Non-interest income is not a substitute for interest income. In another study, non-interest income is considered more stable than income from interest. When testing each component of non-interest income, fees and commissions have a negative effect on risk (Sianipar, 2015). In other words, non-interest income can decrease a bank's risk while trading income has a positive relationship on performance (ROA) in banks. Another study of Indonesian banking in 2011-2015 showed the strongest income component to reduce non-systematic risk (Fadli, 2017) and total risk is fee-based income (Sianipar, 2015).

\section{RESEARCH METHOD}

This research was conducted with 41 conventional banks in Indonesia for the period 2012-2017. The data sources were the annual reports for each bank. The analysis method was multiple regression. The dependent variables in this research were bank performance and bank efficiency. Bank performance was measured by Return on Assets (ROA). The independent variables in this research are non-interest income diversification and efficiency bank. This research also used control variable such as bank size, non-performing loans, and loans. To measure diversification, we used the Adjusted Herfindahl-Hirschman Index (AHHI) from Stiroh and Rumble (2006).

$$
\operatorname{DIV}_{(\mathrm{NOI})}=1-\left\lceil\left(\frac{\mathrm{NII}}{\mathrm{NOI}}\right)^{2}+\left(\frac{\mathrm{NON}}{\mathrm{NOI}}\right)^{2}\right\rceil
$$

Net operating income (NOI) can be calculated using the sum of net interest income (NII) and non-interest income $(\mathrm{NON})$. The index values vary from 0.0 to 0.5 . If the index resulted the value of 0.00 , it means the level of diversification is minimum or the operating income generates only from one source (interest income or non interest income. A value of 0.5 is perfect diversification where each income source is the same. Therefore, the income has a higher value than a more diverse mixture.

$$
\mathrm{DIV}_{(\mathrm{NON})}=1-\left\lceil\left(\frac{\mathrm{FEE}}{\mathrm{NON}}\right)^{2}+\left(\frac{\mathrm{TRD}}{\mathrm{NON}}\right)^{2}+\left(\frac{\mathrm{OTR}}{\mathrm{NON}}\right)^{2}\right\rceil
$$

Non-interest income can commonly be separated into three parts: FEE, TRD, and OTR. FEE is the part of noninterest income that comes from fees and commissions. TRD, or trading income, is income from trading activities, foreign exchange transactions, or trading 
securities. OTR is income from other non-interest income.

Based on previous studies, bank size in this study is calculated by the logarithm of total assets ( $\log ($ Total Asset)) (Hidayat. Makoto, and dan Hiroaki, 2012; Sianipar, 2015). The model used in this research is:

$$
\begin{gathered}
\text { ROA }=\beta_{0}+\beta_{1} \text { DIV }_{(\mathrm{NOI}) \mathrm{i}}+\beta_{2} \text { DIV }_{(\mathrm{NON}) \mathrm{i}}+\beta_{3} \text { SIZE }_{\mathrm{i}} \\
+\beta_{4} \text { LOAN }_{\mathrm{i}}+\beta_{5} \mathrm{NPL}_{\mathrm{i}}+\varepsilon_{\mathrm{i}}
\end{gathered}
$$

\section{RESULTS AND DISCUSSION}

\subsection{Descriptive Statistics}

Table 1. Descriptive Statistics
This study examines 41 conventional banks out of 112 banks in Indonesia (Islamic and conventional banks). The level of non-income diversification is not too high with a value of 0.29 , which is not really close to 0.5 . In the other hand, the level of non-interest income diversification is high enough because the mean of 0.42 is closer to 0.5 than to 0.0 . It means that the value of non-performing loan (NPL) still controllable because central bank determine 5\% as maximum standard in NPL. Bank with NPL $<5 \%$ still be considered safe. The highest NPL is $12.2 \%$ and the lowest is $0.08 \%$.

\begin{tabular}{|l|c|c|c|c|}
\hline & Mean & Max. & Min. & S. Dev \\
\hline ROA & 0.009959 & 0.046889 & -0.077939 & 0.014233 \\
\hline DIV $_{\text {NOI }}$ & 0.293703 & 0.500000 & 0.033190 & 0.112072 \\
\hline DIV $_{\text {NON }}$ & 0.425220 & 0.665113 & -1.893160 & 0.232729 \\
\hline NPL & 0.026639 & 0.122800 & 0.000800 & 0.018754 \\
\hline LOAN & 0.653582 & 0.808694 & 0.396396 & 0.079213 \\
\hline SIZE & 17.23097 & 20.84216 & 13.69075 & 1.688788 \\
\hline
\end{tabular}

\subsection{Regression Results}

The results in Table II show the relationship between dependent variables and independent variables. Income diversification (DIVNOI), non-interest income diversification (DIVNON), bank size (SIZE), and nonperforming loans (NPL) significantly influenced a bank's performance (Sig. $<0.05)$. At the same time, the ratio of loans to total assets (LOAN) was not proven to have an effect on bank performance.

Table 2. Results of regression testing

\begin{tabular}{|l|c|c|c|c|c|}
\hline & B & S.E & t & Sig. & Decision \\
\hline (Constant) & -0.035 & 0.021 & & & \\
\hline LOAN & 0.007 & 0.024 & 0.311 & 0.758 & NS \\
\hline SIZE & 0.004 & 0.001 & 5.204 & $0.000 * * *$ & S \\
\hline NPL & -0.458 & 0.103 & -4.439 & $0.000 * * *$ & S \\
\hline DIV $_{\text {NOI }}$ & -0.041 & 0.015 & -2.742 & $0.010 * *$ & S \\
\hline DIV $_{\text {NON. }}$ & -0.019 & 0.009 & -2.036 & $0.049 * *$ & S \\
\hline
\end{tabular}

***, **, *, Significant on 1\%, 5\%, and 10\%; Note: S =Significant; NS=Not Significant

Income diversification (DIVNOI) has a negative effect on bank performance based on the coefficient $(\beta=$ $-0.041)$. Increasing revenue diversification can cause a decline in bank performance. The relationship between non-interest income diversification (DIVNON) and bank performance is negative $(\beta=-0.019)$. Increasing revenue diversification can cause a decline in bank performance. The relationship between size bank (SIZE) and bank performance is positive $(\beta=0.004)$. Increasing size bank (SIZE) can increase bank performance. The relationship between non-performing loans (NPL) and bank performance is negative $(\beta=-0.458)$. Decreasing non- 
performing loans (NPL) can increase bank performance. Based on the results of this study, it is possible to formulate the equation from the multiple linear regression test:

ROA $=-0.035-0.041$ DIVNOI -0.019 DIVNON + $0.004 \mathrm{SIZE}-0.458 \mathrm{NPL}+\varepsilon$

Table III gives a correlation coefficient (R) of 0.767 , which indicates that the independent variables (income

Table 3. F-test results diversification, non-interest income diversification, loan, and size) and the dependent variable (bank performance) have a very strong correlation. R Square (the coefficient of determination) equals 0.588 . This means that the independent variable has the ability to determine bank performance in Indonesia. In other words, independent variables can explain about $58.8 \%$ of bank performance in Indonesia. The remaining $41.2 \%$ was influenced by other factors that are not covered not in this study.

\begin{tabular}{|l|r|r|r|r|}
\hline Model & R & R Square & Adjusted R Square & \multicolumn{1}{c|}{$\begin{array}{c}\text { Std. Error of the } \\
\text { Estimate }\end{array}$} \\
\hline 1 & $0.767^{\mathrm{a}}$ & 0.588 & 0.529 & 0.0079212 \\
\hline
\end{tabular}

Based on simultaneous testing (F-test), the F-value is 9.972 with a significance level of 0.000 . The result indicates that the F-value is higher than the F-table value $($ F-value $>$ F-table; $9.972>2.49 ;$ F-table $=2.49$ at a significance level of $5 \%$ ). Therefore, the test results mean that the variables of income diversification, noninterest income diversification, size, loan, and NPL simultaneously have significant influence on bank performance.

\subsection{Discussion}

The main points of interest in this research, income diversification and non-interest income diversification, have negative effects on bank performance. This study is in line with previous research that has stated negative effects from diversification activities. Abuyazed et al. (2018) found that there was a negative relationship between the diversification of income and bank risk. Diversification activities can increase expenditures or costs in supervision activities (Cerasi and Daltung, 2000) and can reduce competitive advantage at the same time because the companies are doing activities outside their capability (Klein and Saidenberg, 1998). It can also increase agency cost (Rotemberg, and Saloner, 1994) as a result of agency conflict where managers can ignore the interests of shareholders and try to increase their personal profits or personal interest (Leaven and Levine, 2007). According to agency theory, when the owner is not a manager, then agency conflict will occur. In fact, investment is influenced by the efforts and determination of the manager (Jensen and Meckling, 1976; Riaz, Shahab, Bibi, and Zeb, 2016;). Diversification has the potential to cause inefficiency (Rajan, Servaes, and Zingales, 2000). Diversification can be a double-edged sword where one side can make a company more profitable but the other side can cause the company to pay much more for diversification activities (Kang, Lee, and Yang, 2010). Research on 412 banks and other financial institutions in France during the years 20022012 found that diversified activities could reduce performance (Jouida, Bouzgarrou, and Hellara, 2017).

This research also shows that interest income is still a crucial component in bank performance although the ratio of loans to assets (LOAN) does not significantly influence bank performance. This means that loan quality may still be more important than loan quantity. Poor quality loans will cause inefficiency because they will increase non-performing loans and increase costs. Therefore, banks must concentrate on controlling loan quality in an expanding market. Loan quality is part of the relationship between non-performing loans and bank performance. Non-performing loans have a negative effect on bank performance. Increased bad loan problems have encouraged banks to increase cost in covering potential loses from bad loan. The high bad loan, the high cost to cover it. Non-performing loans can be costly for a bank. By reducing NPL, banks can reduce the burden of forming reserves against losses out of productive assets. Lower NPL will increase profits and bank performance.

Table 4. Interest income and non-interest income

\begin{tabular}{|c|c|c|}
\hline Year & II (\%) & NII (\%) \\
\hline 2012 & $75.71 \%$ & $24.29 \%$ \\
\hline 2013 & $76.64 \%$ & $23.36 \%$ \\
\hline 2014 & $79.28 \%$ & $24.60 \%$ \\
\hline 2015 & $75.40 \%$ & $2 \%$ \\
\hline
\end{tabular}




\begin{tabular}{|c|c|c|}
\hline 2016 & $73.18 \%$ & $26.82 \%$ \\
\hline 2017 & $75.61 \%$ & $24.39 \%$ \\
\hline II = Interest Income (\%) ; NII = Non-interest Income (\%). Sources: SPI OJK \\
\hline
\end{tabular}

In Indonesia, banks still depend on interest income. The income from interest is 70-80\% (Table IV) and income from non-interest sources is still below $30 \%$. This condition causes banks in Indonesia to be very vulnerable to external economic conditions that affect loan quality. This encourages banks in Indonesia to add new income sources in anticipation of risk from interest income. Fortunately, industry NPL rates are still maintained at a safe point. Bank NPL rates in Indonesia are also still better than in some other countries (Figure I). The NPL rate in Indonesia is $2.9 \%$, which is better than in the global percentage $(3.9 \%)$, and it is the same as Thailand $(2.9 \%)$. The number is also better than for countries such as Brazil (3.8\%), India (7.6\%), Turkey (3.2\%), and South Africa (3.2\%). There are several ways to save bad loans (Kasmir, 2014):

Rescheduling is the action of extending the terms of credit or installments.

Reconditioning is the action of changing existing requirements such as capitalization (converting interest to principal debt), delaying payment of interest until a certain time, reducing interest rates, and exempting interest on the condition that the customer is no longer able to pay the loan.

Restructuring is the action where the bank adds to the customer's loan on the assumption that the customer needs funds to improve the stability of the business. Another assumption involved is the belief that the customer's business still has business viability.

Combination is the combination of the three previous actions in resolving bad loans.

Taking the collateral is the last step taken by the bank if there is no solution or if the customer is at the last point in the inability to repay their loan.

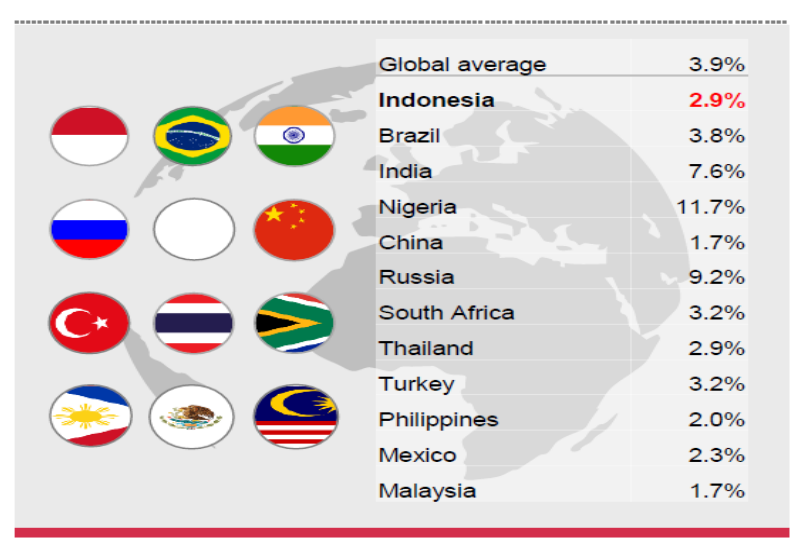

Figure 1 NPL in Indonesia compared to other countries. Source: Indonesia Survey Banking 2016.
In the long term, the bank still needs to maximize non-interest income. Creating fee-based income can be an effort to increase non-interest income. The bank develops new services by investing in new technology such us digital banking, QR payments, e-payments, and other services. Technology will also increase operational costs and create efficiencies that maximize profits for banks.

Digital strategy can be part of corporate strategy because in the future digital services will change the business competition map, including in banking industry. Many banks include a digital strategy in their corporate strategy. In Indonesia, BTN and DBS have launched a digital banking service. In the future, everyone will be able to access all bank services using only a smartphone without directly dealing with any bank personnel. The opportunity for officeless services will increase as smartphone ownership in Indonesia continues to grow (Figure II).



Figure 2 Smarphone users in Indonesia. Source: Digital Banking Survey 2018.

However, digital strategies for banks are not easy to apply for several reasons. Existing technologies are difficult to integrate. There are regulatory problems, inflexible teams and businesses, and limited teams of workers that have appropriate skills, for example (PwC Survey: Digital Banking in Indonesia, 2018). To maintain existing income or products, banks can implement a two-channel strategy where banks engage in diversity activities and keep existing activities at the same time. This means that banks try to maintain their existing main income source (interest income) while they generate new income sources. This strategy can also direct the bank's focus in an offline channel and an online channel to interact with customers. 


\section{CONCLUSION}

This research provides empirical findings that diversification decreases bank performance. Increasing income diversification and non-interest income will decrease bank performance. There is a negative relationship between diversification and bank performance. This result is in line with the theory about dark diversification where income diversification can have negative impacts on the company and diversification can cause inefficiency. The diversification activities can potentially cause agency conflict. In the last analysis, banks spend too much money funding before- and after-diversification activities. This research also finds that non-performing loans and bank size significantly influence bank performance. Finally, this study does not show a relationship between loan proportions and bank performance. The conclusion is that bank performance is influenced more by loan quality than loan quantity.

\section{RESEARCH LIMITATIONS}

This research only analyzes commercial banks in Indonesia. Future studies can conduct a comparison study between commercial banks and Islamic banks regarding the level of diversification. This study only focuses on income diversification. Future studies can add geographic diversification so that researchers can compare the implementation of this kind of diversification in banks and can analyze its effect on bank performance.

\section{REFERENCES}

[1] Abuzayed, B., Al-Fayoumi, N., and Molyneux, P. 'Diversification and bank stability in the GCC,' Journal of International Financial Markets, Institutions and Money, 2018, 1-25.

[2] Alhassan, A. L. 'Income diversification and bank efficiency in an emerging market,' Managerial Finance, 41 (12), 2015, pp. 1318-1335.

[3] Benito-Osorio, D., Guerras-Martin, L. A., and Zuniga-Vicente, J. A. Four decades of research on product diversification: a literature riview. Management Decision 50 (2), 2012, pp. 325-344.

[4] Cerasi, V., and Daltung, S. 'The optimal size of a bank: cost and benefit of diversification', European Economic Review, 44 (9), 2000, pp. 1701-1726.

[5] Deng, S.E. and Elyasiani, E 'Geographic diversification, bank holding company value and risk', Journal of Money Credit Bank, 40 (6),2008, pp. $1217-1238$.

[6] DeYoung, R. and Rice, T. 'Non-interest income and financial performance at US commercial banks,' The Financial Review, 39, 2004, pp. 101127.

[7] DeYoung, R. and Roland, K.P. 'Product mix and earnings volatility at commercial banks: evidence from a degree of total leverage model', Journal of Financial Intermediation, 10 (1), 2001, pp. 54-84.

[8] Fadli, J.A. Pengaruh Diversifikasi terhadap Risiko dan Kinerja Bank dengan Pemoderasi Tipe Kepemilikan Ultima Keluarga dan Negara. Thesis. Yogyakarta: Universitas Gajah Mada, 2017.

[9] Hidayat, W., Makoto, K., and Hiroaki, M. 'Bank risk and non-interest income activities in the Indonesian banking industry', Journal of Asian Economics, 23, 2012, pp. 335-343.

[10] Hillier, D., Ross, S. W., Jaffe, J., and Jordan, B. Corporate Finance. Berskhire: McGraw-Hill, 2010.

[11] Pwc Website."PwC Survey: Digital Banking in Indonesia".

https://www.pwc.com/id/en/publications/assets/fina ncialservices/digital-banking-survey-2018pwcid.pdf, 2018.

[12] Pwc Website. "Indonesia Banking Survey 2017". https://www.pwc.com/id/en/publications/assets/fina ncialservices/ibs-2017.pdf, 2017.

[13] Jensen, M., and Meckling, W. 'Theory of the firm: Managerial behavior, agency cost and ownership structure', Journal of financial Economics, 3 (4), 1976, pp. 305-360.

[14] Jouida, S., Bouzgarrou, H., and Hellara, S. 'The effects of activity and geographic diversification on performance: Evidence from French financial institutions', Research in International Business and Finance, 39 (B), 2017, pp. 920-939.

[15] Kang, H., Lee, S., and Yang, H. 'The effects of product diversification on firm performance and complementarities between products; a study of US casinos', International Journal of Hospitality Management, 30 (2), 2010, pp. 409-421.

[16] Kasmir. Analisis Laporan Keuangan. Jakarta: PT Raja Grafindo Persada, 2014.

[17] Klein, P., and Saidenberg, M. Diversification, Organization, and Efficiency: Evidence from Bank Holding Companies. Federal Reserve Bank of New York, 1998.

[18] Leaven, L., and Levine, R. 'Is there a diversification discount in financial conglomerates', Journal of Financial Economics 85, 2007, pp. 331-367.

[19] Mintzberg, H., Ahlstrand, B., and Lampel, J. Strategy safari your complete guide through the 
wilds of strategic management. London: PrenticeHall, 2009.

[20] Oyewobi, L. O., Windapo, A. O., and Cattell, K. S. 'Impact of business diversification on South African construction companies' corporate performance', Management of Property and Construction, 18 (2), 2013, pp. 110-127.

[21] Rajan, R., Servaes, H., and Zingales, L. 'The cost of divesity: the diversification discount and inefficient investment', Journal of Finance, 55 (1), 2000, pp. 35-80.

[22] Riaz, Y., Shahab, Y., Bibi, R., and Zeb, S. 'Investment-cash flow sensitivity and financial constraints: evidence from Pakistan', South Asian Journal of Global Business Research, 5 (3), 2016, pp. 403-423.

[23] Rotemberg, J., and Saloner, G. 'Benefits of narrow business strategies', American Economic, 1994, pp. 1330-1349.

[24] Schoar, A. 'Effect of corporate diversification on productivity,' The Journal of Finance, 57, 2002, pp. 2379-2403.

[25] Sianipar, A.S. 'Pengaruh diversifikasi pendapatan terhadap kinerja bank', Jurnal Siasat Bisnis, 19 (1), 2015, pp. 27-35.
[26] Sissy, A. M., Amidu, M., and Abor, J. Y. 'The effect of revenue diversification and cross border banking on risk and return of bank in Africa,' Research in International Business and Finance, 40, 2017, pp. 1-18.

[27] Stiroh, K. and Rumble, A. 'The dark side of diversification: the case of US financialholding companies', Journal of Banking and Finance, 30, 2006, pp. 2131-2161.

[28] Stiroh, K. 'Diversification in banking: is noninterest income the answer', Journal ofMoney, Credit and Banking, 36, 2004, pp. 853-882.

[29] Stiroh, K. 'Do community banks benefit from diversification?'Journal of Financial Services Research, 25, 2004, pp. 135-160.

[30] Stiroh, K. 'A portfolio view of banking with interest and non-interest income', Journal of Money, Credit, and Banking, 28, 2006, pp. 13511361.

[31] Stiroh, K. 'New evidence on the determinants of bank risk', Journal of Financial Services Research, 30, 2006, pp. 237-263. 